\title{
The Effect of Intravenous Administration of a Chimeric Anti-IgE Antibody on Serum IgE Levels in Atopic Subjects: Efficacy, Safety, and Pharmacokinetics
}

\author{
Jonathan Corne, ${ }^{\star}$ Ratko Djukanovic, ${ }^{*}$ Lynette Thomas, ${ }^{*}$ Jane Warner, ${ }^{*}$ Luigi Botta, ${ }^{\ddagger}$ Beatrice Grandordy, ${ }^{\ddagger}$ Daniel Gygax, ${ }^{\ddagger}$ \\ Christoph Heusser, ${ }^{\ddagger}$ Francesco Patalano, ${ }^{\ddagger}$ William Richardson, ${ }^{\ddagger}$ Erich Kilchherr, ${ }^{\ddagger}$ Theophil Staehelin, ${ }^{\ddagger}$ Frances Davis, ${ }^{\S}$ \\ Wayne Gordon, ${ }^{\S}$ Lee Sun, ${ }^{\S}$ Ruey Liou, ${ }^{\S}$ George Wang, ${ }^{\S}$ Tse-Wen Chang, ${ }^{\S}$ and Stephen Holgate* \\ *University Medicine, Southampton General Hospital, Southampton, United Kingdom; ${ }^{\ddagger}$ Ciba-Geigy, Basel, Switzerland; and \\ ${ }^{\S}$ Tanox Biosystems, Inc., Houston, Texas 77025
}

\begin{abstract}
CGP 51901 is a non-anaphylactogenic mouse/human chimeric anti-human IgE antibody that binds to free IgE and surface IgE of IgE-expressing B cells but not to IgE bound to high affinity IgE receptors (FceR1) on mast cells and basophils or low affinity IgE receptors (FceR2) on other cells. A phase 1 double-blind, placebo-controlled, single dose study with doses of 3, 10, 30, and $100 \mathrm{mg}$ of CGP 51901 was conducted in 33 pollen-sensitive subjects who had raised levels of serum IgE and received either intravenous CGP 51901 or placebo. The administration of CGP 51901 was well tolerated and resulted in a decrease of serum free IgE levels in a dose-dependent manner, with suppression after $100 \mathrm{mg}$ of CGP 51901 reaching $>96 \%$. Time of recovery to $50 \%$ of baseline IgE correlated with the dose of administered antibody and ranged from a mean of $1.3 \mathrm{~d}$ for the $3 \mathrm{mg}$ to $39 \mathrm{~d}$ for the $100 \mathrm{mg}$ dose. Total IgE, comprised of free and complexed IgE, increased as stored and newly synthesized IgE bound to CGP 51901. Complexed IgE was eliminated at a rate comparable with the terminal half-life of free CGP 51901 (11-13 d at all doses). Only one subject showed a weak antibody response against CGP 51901. We conclude that the use of anti-human IgE antibody is safe and effective in reducing serum IgE levels in atopic individuals and provides a potential therapeutic approach to the treatment of atopic diseases. (J. Clin. Invest. 1997. 99:879-887.) Key words: IgE • atopic hypersensitivity $\bullet$ rhinitis $\bullet$ monoclonal antibodies $\bullet$ chimeric proteins
\end{abstract}

\section{Introduction}

Atopic diseases are a major cause of morbidity and mortality. The prevalence of both asthma and allergic rhinitis are rising and at present are estimated to be 10-20\% (1). In the United States asthma alone has been estimated to affect between 9 and 12 million people, lead to 1.81 million emergency room visits per year, and cause an annual loss of nearly 3 million working days (2).

\footnotetext{
Address correspondence to Jonathan Corne, University Medicine, Centre Block, Southampton General Hospital, Tremona Rd, Southampton, UK, SO16 6YD. Phone: 44703 794196; FAX: 44703701771.

Received for publication 31 July 1996 and accepted in revised form 19 December 1996.
}

J. Clin. Invest.

(C) The American Society for Clinical Investigation, Inc.

0021-9738/97/03/0879/09 \$2.00

Volume 99, Number 5, March 1997, 879-887
Epidemiological studies have suggested a link between circulating $\operatorname{IgE}$ and atopic disease. With regard to asthma, levels of circulating IgE have been shown to correlate with symptom severity (3), bronchial hyperresponsiveness $(4,5)$ and risk of emergency room admissions (6). In seasonal rhinitis levels of circulating $\operatorname{IgE}$ have been shown to increase in parallel with symptoms during the pollen season $(7,8)$.

IgE binds to the $\alpha$ chain of the high affinity receptor $(\mathrm{Fc} \in \mathrm{R} 1)^{1}$ on mast cells and basophils and to the low affinity receptor $(\mathrm{Fc} \in \mathrm{R} 2)$ on monocytes/macrophages, lymphocytes, epithelial cells, and dendritic cells. Allergen cross-linking of IgE bound to mast cells results in activation of these cells and release of a range of preformed and newly generated vasoactive and bronchoconstrictive substances leading to the immediate hypersensitivity type responses such as the early phase of airway obstruction that follows experimental allergen challenge. The identification of the cytokines IL-4, IL-5, IL-6, and TNF $\alpha$ within the mast cell (9) and demonstration of their release after IgE cross-linking (10-12) also suggests an important role for IgE in the late phase of airway obstruction and the associated increase in bronchial hyperresponsiveness.

Recent work has highlighted the potential importance of IgE with regard to T cell responsiveness. Antigen-IgE complexes bound to $F c \in R 2$, and possibly the FceR1 receptors recently identified on antigen presenting cells $(13,14)$, have been shown to amplify the $\mathrm{T}$ cell response to allergen by facilitating antigen presentation to antigen-specific T cells (15), and, consistent with this, a recent study has shown that treatment of mice with a monoclonal anti-mouse $\operatorname{IgE}$ antibody inhibits the T cell production of IL-4 and the airway eosinophilia resulting from challenge with house dust mite antigen (16). This response was not mast cell-dependent since mast cell-deficient mice develop a normal eosinophilic response to antigen provocation (17) but rather, it appeared to be mediated through the low-affinity $\operatorname{IgE}$ receptor. It would appear that $\mathrm{IgE}$, acting directly through $F c \in R 2$, plays a central role in the induction of a Th2-type response and forms part of a positive feedback loop leading to further increases in IgE and causing airway eosinophilia. Therapy effectively targeted against IgE, that interferes with its binding to both high and low-affinity receptors, should inhibit this amplification as well as reducing the early and late phase airway responses through inhibition of mast cell degranulation. Such a therapy would therefore be specifically directed against a central component of the inflammatory response in contrast to currently available treatments that are not specific, are often limited by side effects and have failed to

1. Abbreviations used in this paper: $\mathrm{Fc} \in \mathrm{R} 1$, high affinity $\mathrm{IgE}$ receptor; Fc $\in R 2$, low affinity IgE receptor; HRP, horseradish peroxidase; PBSTT, PBS plus $0.5 \mathrm{ml} /$ liter Tween 20 and $0.1 \mathrm{~g} /$ liter Thimerosal. 
stem the increase in morbidity and mortality associated with atopic diseases.

CGP 51901 is a mouse/human chimeric anti-IgE antibody produced by recombinant DNA methodology. It consists of the heavy and light chain variable regions of a parent murine antibody and the heavy and light chain constant regions of the human $\kappa$ and $\gamma 1$ antibody isotypes (18). It binds to the lowand high-affinity receptor-binding portions of human $\mathrm{IgE}$ located in the $\mathrm{C} \epsilon 3$ domain. It therefore binds to circulating $\operatorname{IgE}$ and $\operatorname{IgE}$ expressed on $\mathrm{B}$ cells since the $\operatorname{IgE}$ molecule is anchored within the $\mathrm{B}$ cell membrane with the $\mathrm{C} \epsilon 3$ domain exposed. CGP 51901 does not bind to IgE bound to mast cells and basophils or cells bearing the $F c \in R 2$ receptor since the epitope on $\operatorname{IgE}$ against which it is directed is attached to and thus hidden within the receptor. Consequently it does not trigger anaphylaxis nor cause lysis of cells bearing $\operatorname{IgE}$ receptors. Chimerization of the antibody results in a reduction of its potential immunogenicity in man and an increase in its expected half-life (19) since $90 \%$ of the antibody response is directed against the constant region (20). The utilization of the $\gamma 1$ constant region optimizes its potential for complement and cellmediated lysis of IgE-expressing B cells (21).

After extensive in vitro and animal experiments we have hypothesized that administration of CGP 51901 to humans would be safe and effective in reducing levels of circulating IgE. We have therefore performed a phase 1 study in which we have administered CGP 51901 intravenously in increasing doses to atopic, non-asthmatic individuals sensitive to grass pollen. Volunteers were monitored for effects on serum levels of IgE as well as levels of CGP 51901, development of antiCGP 51901 antibodies and other clinical and laboratory markers of safety. As a secondary outcome variable, effects on skin prick tests to pollen allergen were also measured.

\section{Methods}

This was a double-blind, placebo-controlled randomized, single dose, sequential group study of ascending doses of 3,10,30, and $100 \mathrm{mg}$ of CGP 51901. The study was approved by the Southampton University and Hospital Joint Ethics Committee and was conducted in accordance with the Declaration of Helsinki. All volunteers gave their written informed consent.

33 male volunteers aged 18 to 60 years participated in the study. All had positive skin prick tests to mixed grass pollens, a positive radio allergen absorbance test (RAST) to the same grass pollen mix, and total serum $\mathrm{IgE}$ levels between $100 \mathrm{IU} / \mathrm{ml}$ and $850 \mathrm{IU} / \mathrm{ml}$ at the time of screening. None had a history of asthma or non-seasonal rhinitis, parasitic infections, previous anaphylactic reactions or allergy to mice. None were taking phenothiazines, oral corticosteroids or tricyclic anti-depressants and none suffered from any other concomitant disease. As a further safety measure an intradermal skin test to CGP 51901 was performed on each volunteer and any with a positive reaction to CGP 51901 (a wheal $3 \mathrm{~mm}$ greater than the negative, saline control) was excluded from the study. The protocol did not include skin testing with CGP 51901 after the infusion since the repeated intradermal administration of a protein is known to be highly effective in stimulating an immune response.

Skin prick testing. Skin prick testing was performed using a combination of 5 grass pollens (Ky Blue, Meadow Fescue, Orchard, Per Rye, Redtop, Sweet Vermal, Timothy) (Dome/Hollister Stier, Washington) using the puncture technique (22). Tests were considered positive if they caused a wheal with a diameter $3 \mathrm{~mm}$ greater than that the negative, saline control. For follow up the area of the skin test wheals were measured by planimetry.
Screening visit. After taking a full medical history and performing a physical examination an electrocardiograph was performed and $35 \mathrm{ml}$ of blood drawn for differential cell count, liver function tests, urea and electrolytes, and levels of total serum $\mathrm{IgE}$, complement $\mathrm{C} 4$ and circulating globulins. An abnormal result (exceeding 2 standard deviations) for any of these variables (except $\operatorname{IgE}$ ) led to exclusion from the study.

Study design. Volunteers were dosed in groups of nine, within each group six receiving intravenous CGP 51901 in $40 \mathrm{ml}$ of phosphate buffered saline (PBS) with $0.02 \%$ polysorbate 80 and three receiving placebo consisting of $40 \mathrm{ml}$ of PBS with $0.02 \%$ polysorbate 80 only. Initially $0.1 \mathrm{mg}$ of CGP 51901 or an equivalent volume of placebo was infused via a syringe pump (IVAC P2000, IVAC Ltd., Basingstoke, UK) over $5 \mathrm{~min}$. Volunteers were then monitored for signs of hemodynamic compromise over $30 \mathrm{~min}$ and, if stable, the remainder of the intravenous dose was administered over a further $30 \mathrm{~min}$. Blood was drawn for measurements of IgE and CGP 51901 levels as well as immune and biochemical parameters after $30 \mathrm{~min}, 1,2,4,6,8$, and $24 \mathrm{~h}$ and then at 5, 8, 11, 15, 22, 29, 43, $57 \mathrm{~d}$ and 3 mo after dosing. Volunteers were then seen at monthly intervals to monitor recovery of $\mathrm{IgE}$ levels. Skin prick tests to grass pollen were performed at all visits from day 5 onwards.

Measurement of CGP 51901. Serum levels of CGP 51901 were measured by an enzyme linked immunosorbent assay (ELISA) based on a monoclonal anti-idiotypic antibody, (CA69-76-5) to CGP 51901 which was conjugated to horseradish peroxidase (HRP) and acted both as a capturing and signalling antibody. Briefly, Immulon 2 Microtiter plates were coated overnight at room temperature with 100 $\mu \mathrm{l} /$ well of an anti-idiotypic antibody-coating solution with an antibody concentration of $0.5 \mu \mathrm{g} / \mathrm{ml}$ in CMF-PBS-pHix (calcium and magnesium free phosphate buffered saline containing $80 \mu \mathrm{l} /$ liter pHix buffer preservative obtained from Socochim SA, Lausanne, Switzerland). After removal of the coating solution, unoccupied binding sites were blocked by incubation at $22^{\circ} \mathrm{C}$ with $200 \mu \mathrm{l} /$ well of Blotto (PBS plus $0.5 \mathrm{ml} /$ liter Tween 20 and $0.1 \mathrm{~g} /$ liter Thimerosal containing $5 \%$ non-fat dry milk powder for $2 \mathrm{~h}(23,24)$. The plates were then washed four times with $200 \mu \mathrm{l} /$ well of PBS plus $0.5 \mathrm{ml} /$ liter Tween 20 (Fluka Chemicals AG, CH-9470 Buchs, Switzerland) and $0.1 \mathrm{~g} /$ liter Thimerosal (PBSTT) (Sigma Chemical Co., St. Louis, MO). To prepare the standards, CGP 51901 was diluted in Blotto at concentrations ranging from $2 \mathrm{ng} / \mathrm{ml}$ to $50 \mathrm{ng} / \mathrm{ml}$. $10 \mu \mathrm{l}$ of either standard, serum sample or control were then added in triplicate to the appropriate wells already containing $40 \mu \mathrm{l}$ of Blotto. After $3 \mathrm{~h}$ at room temperature the solution was decanted, the plates washed again and equilibrated at $22^{\circ} \mathrm{C}$ for $1 \mathrm{~h}$ in the dark with $50 \mu \mathrm{l}$ of the HRP conjugate solution diluted to $0.25 \mu \mathrm{g} / \mathrm{ml}$ in Blotto. After decanting and washing, the wells were incubated with $100 \mu \mathrm{l}$ of freshly prepared tetramethylbenzidine ( $0.1 \mathrm{ml}$ of a $1 \%$ tetramethylbenzidine (E Merck, Zurich, Switzerland) in dimethylformamide, $0.2 \mathrm{ml} 1 \mathrm{M}$ sodium acetate and $12 \mu \mathrm{l} 3 \% \mathrm{H}_{2} \mathrm{O}_{2}$ added to $90.7 \mathrm{ml}$ deionized water) for $30 \mathrm{~min}$ at $22^{\circ} \mathrm{C}$ in the dark. The reaction was stopped by adding $50 \mu \mathrm{l} /$ well of $1 \mathrm{M} \mathrm{H}_{2} \mathrm{SO}_{4}$. Absorbance was measured at $405 \mathrm{~nm}$ in a microplate reader (Molecular Devices, Type $V_{\max }$, Paul Bucher, Analytil und Biotecnologie, Basel, Switzerland) and the data processed with RIASmart ${ }^{\mathrm{TM}}$ software package (Canberra Packard Int SA, Zurich, Switzerland) using a smooth line curve-fitting program. The working range of the assay was between 2 and $50 \mathrm{ng} / \mathrm{ml}$.

Measurement of serum total IgE. The assay for total IgE was a chemiluminescence sandwich immunoassay based on a mouse antihuman $\operatorname{IgE} \mathrm{mAb}$ covalently coupled to paramagnetic particles (Ciba Corning Diagnostics, East Walpole, MA), on magnetic separation of bound from unbound reagents and on a revealing anti-IgE $\mathrm{mAb}$ labelled with an acridinium ester (Ciba-Geigy Ltd, Basel, Switzerland). This assay measures both uncomplexed (free) $\operatorname{IgE}$ and $\operatorname{IgE}$ complexed with CGP 51901. CGP 51901 binding to IgE does not interfere with the binding of either the capturing or the revealing antibody of the assay. Since the assay was designed to measure both free and CGP 51901-complexed IgE, all samples were preincubated with a 
large molar excess of CGP 51901 before the assay in order to establish qualitative $\operatorname{IgE}$ complexing and therefore reduce heterogeneity of the reactant. For the assay, $50 \mu \mathrm{l}$ of serum were mixed with $50 \mu \mathrm{l}$ of CGP 51901 in phosphate buffered saline containing $0.5 \mathrm{~g} /$ liter Tween 20 (Fluka Chemie AG, Switzerland), $10 \mathrm{~g} /$ liter bovine serum albumin (Fluka Chemie AG, Switzerland) and $0.2 \mathrm{ml} /$ liter of $10 \% \mathrm{NaN}_{3}(\mathrm{E}$ Merck, Zurich, Switzerland) resulting in a final concentration of 40 $\mu \mathrm{g} / \mathrm{ml}$ of CGP 51901. After preincubation for $1 \mathrm{~h}$ at $37^{\circ} \mathrm{C}, 25 \mu \mathrm{l}$ of this solution was mixed with $500 \mu \mathrm{l}$ of solid phase suspension and the mixture incubated for $2 \mathrm{~h}$ at room temperature. The unbound material was removed and the solid phase washed once with $1 \mathrm{ml}$ of deionized water before equilibration with the Lite Reagent prepared from a purified anti-human IgE mAb-AB 669-6-7 (Asthma and Allergy Research, Ciba-Geigy Ltd.) coupled to an acridinium ester (Ciba Corning Diagnostics). After $3 \mathrm{~h}$ incubation at room temperature, excess solution was removed and the bound material washed twice with 750 $\mu l$ of millipore water and placed in a luminometer (Magic Lite Analyzer II, Ciba Corning Diagnostics). The standard curve, based on a built-in master curve, was adjusted to the condition of the assay by means of a two-point calibration system. The working range of the assay is between 2 and $460 \mathrm{IU} / \mathrm{ml}$.

Measurement of free IgE in serum. Free IgE was measured using an ELISA technique with CGP 51901 as the capture antibody. This avoids detection of $\operatorname{IgE}$ that is already complexed with CGP 51901 and thus measures both baseline IgE levels before infusion of CGP 51901 and remaining free (uncomplexed) IgE after infusion. A biotinylated monoclonal anti-IgE which was specific for an epitope of the IgE molecule different from that of CGP 51901 was used as the revealing antibody. To prepare IgE standards, a serum of known IgE concentration was diluted with PBS/BSA/TW (Phosphate buffered saline containing $1 \%$ bovine serum albumin (Fluka Chemie AG, Switzerland), $0.5 \mathrm{ml} /$ liter Tween 20 and $0.2 \mathrm{ml} /$ liter of a $10 \% \mathrm{NaN}_{3}$ solution) to concentrations between 1 and $144 \mathrm{IU} / \mathrm{ml}$. M-129 B Dynatech 96-well ELISA-plates were coated overnight at room temperature with $50 \mu \mathrm{l} /$ well of CGP 51901 coating solution $(1 \mu \mathrm{g} / \mathrm{ml}$ in coating buffer). The coating solution was removed and unoccupied sites blocked by incubating overnight at $4^{\circ} \mathrm{C}$ with $200 \mu \mathrm{l} /$ well of assay buffer. After washing three times with $200 \mu \mathrm{l} /$ well of PBSTT, standard point solutions, controls $(50 \mu \mathrm{l})$ and test sera $(5 \mu \mathrm{l}$ in $45 \mu \mathrm{l}$ of buffer) were added to the appropriate wells in triplicate and incubated for $1 \mathrm{~h}$ at room temperature. The plates were washed again and, after adding $50 \mu \mathrm{l} /$ well of a 1:5000 dilution of the biotinylated antibody, incubated again for $1 \mathrm{~h}$ at room temperature. After washing they were incubated for a further $1 \mathrm{~h}$ at room temperature with $50 \mu \mathrm{l} /$ well of avidin alkaline phosphatase (Calbiochem, $0.5 \mathrm{mg} / \mathrm{ml}$, diluted 1:2000 in substrate buffer consisting of $97 \mathrm{ml} /$ liter diethanolamine (E Merck, Darmstadt, Germany). $0.2 \mathrm{ml} /$ liter of $10 \% \mathrm{NaN}_{3}$ (E Merck, Zurich, Switzerland) and $0.1 \mathrm{~g} \mathrm{MgCl} 2.6 \mathrm{H}_{2} \mathrm{O}$ (E Merck) dissolved in $900 \mathrm{ml}$ deionized water with the $\mathrm{pH}$ adjusted to 9.8 with $10 \mathrm{M} \mathrm{HCl}$ ). The washing was repeated and followed by addition of $150 \mu \mathrm{l} /$ well of p-nitrophenyl phosphate (Sigma Chemical Co.) in substrate buffer. The mixture was incubated at room temperature for $20 \mathrm{~min}$, the reaction stopped by adding $50 \mu \mathrm{l} /$ well of $1 \mathrm{~N} \mathrm{NaOH}$, and the optical density was read at $405 \mathrm{~nm}$ using a Dynatech MR 7000 ELISA reader (Microtec Produkte AG, Embrash-Embraport, Switzerland). The working range of the assay was between 9 and $500 \mathrm{IU} / \mathrm{ml}$.

Analysis of serum IgE by HPLC. Serum samples were analyzed on a Beckman System Gold HPLC (Beckman, Nyon, Switzerland) using a Sorbax Bio-Series GF-450 molecular sieve column (Rockland Technologies, Newport, DE) equilibrated and developed in $0.2 \mathrm{M}$ sodium phosphate buffer, $\mathrm{pH} 7.2$, at a flow rate of $0.5 \mathrm{ml} / \mathrm{min}$. $50 \mu \mathrm{l}$ of serum were injected per column run. Fractions of $200 \mu \mathrm{l}$ were collected and analyzed for IgE by the chemiluminescence assay for total IgE.

Measurement of serum anti-CGP 51901. The antibody response to CGP 51901 was assayed using a double-antibody capture ELISA based on CGP 51901 as the capture antibody and the revealing antibody. Endogenous IgE was blocked by pre-incubating samples with an excess of a mouse anti-IgE monoclonal antibody which binds to the same epitope as CGP 51901 and has a higher affinity for IgE. Standards were prepared using dilutions of $\mathrm{Ab}$ 69-76-5 in Blotto (0-60 $\mathrm{ng} / \mathrm{ml}$ ). Wells of Immulon 2 Microtest plates were coated overnight at room temperature with $100 \mu \mathrm{l} /$ well of CGP 51901 in CMF-PBS-pHix $(0.5 \mu \mathrm{g} / \mathrm{ml})$. The coating-solution was removed and unoccupied binding sites were blocked by overnight incubation at $4^{\circ} \mathrm{C}$ with $200 \mu \mathrm{l} /$ well of Blotto. The plate was then washed four times with $200 \mu \mathrm{l} /$ well PBSTT. To neutralize endogenous IgE $50 \mu$ l of test serum was preincubated for $1 \mathrm{~h}$ at room temperature with $50 \mu \mathrm{l}$ of Blotto containing mAb 669-1251 (Ciba-Geigy, Ltd.) $(30 \mu \mathrm{l} /$ well) and $20 \mu \mathrm{l}$ of this solution was added to each well and incubated with $30 \mu \mathrm{l} /$ well of Blotto for $2 \mathrm{~h}$ at room temperature. The plate was then washed again and $100 \mu \mathrm{l} / \mathrm{well}$ of HRP-CGP $51901(0.3 \mu \mathrm{g} / \mathrm{ml}$ in Blotto $)$ were added and incubated for $1 \mathrm{~h}$ at room temperature. After washing, $100 \mu \mathrm{l} /$ well of peroxidase substrate (TMB) solution were added and incubated for $30 \mathrm{~min}$ at room temperature. The reaction was stopped by adding 50 $\mu \mathrm{l} /$ well of $1 \mathrm{~N} \mathrm{H}_{2} \mathrm{SO}_{4}$ and the plates read at $450 \mathrm{~nm}$ using a Dynatech MR7000 ELISA reader. The concentrations of anti-CGP 51901 were expressed in ng equivalents $/ \mathrm{ml}$ using the anti-idiotypic $\mathrm{mAb}$ against anti-CGP 51901 (Ab 69-76-5) as the reference. The lower limit of detection was $5 \mathrm{ng}$ equivalents $/ \mathrm{ml}$ of anti-idiotypic $\mathrm{mAb}$.

All the assays were validated using normal sera to which known concentrations of IgE, CGP 51901 and IgE-CGP 51901 complexes had been added. Within the working range of the curve, intra and interassay coefficients of variation were $<10 \%$.

Basophil histamine release. To test the effect of administration of CGP 51901 on the release of mediators of the immediate phase reaction, $40 \mathrm{ml}$ of blood was taken for assay of basophil histamine release immediately before administration of the infusion and at $6 \mathrm{~h}$ and $8 \mathrm{~d}$ after the infusion. The leukocytes were then separated into layers by density centrifugation (25). Briefly, the $40 \mathrm{ml}$ of whole blood was diluted $1: 1.5$ with $0.9 \%$ saline and a cushion of $1.080 \mathrm{~g} / \mathrm{cm}^{3}$ Percoll (Pharmacia, Sollentuna, Sweden) was carefully underlaid followed by centrifugation for $13 \mathrm{~min}$ at $175 \mathrm{~g}$. The upper layer was harvested and centrifuged at $100 \mathrm{~g}$ for $8 \mathrm{~min}$. The cells were then washed twice in PAG (1,4-25 mM piperazinediethanesulphonic acid buffer, $110 \mathrm{mM}$ $\mathrm{NaCl}$ and $5 \mathrm{mM} \mathrm{KCl}$ at $\mathrm{pH} 7.3$ containing $0.003 \%$ wt/vol human serum albumin and $0.1 \% \mathrm{wt} / \mathrm{vol} \mathrm{D}$-glucose) and resuspended in PAGCM (PAG supplemented with $1 \mathrm{mM} \mathrm{MgCl} 2$ and $1 \mathrm{mM} \mathrm{CaCl}_{2}$ ). For histamine release assay cells were incubated at $37^{\circ} \mathrm{C}$ in the presence of buffer alone, $25 \%$ trichloroacetic acid, anti-IgE (Serotec, Oxford, UK) (0.01-1 $\mu \mathrm{g} / \mathrm{ml})$, formyl-methionyl-leucyl-alanine (Sigma Ltd., Poole, UK) $(1 \mu \mathrm{M})$ or calcium ionophore A23187 (Sigma Ltd.) $(1 \mu \mathrm{g} / \mathrm{ml})$. Mediator release was allowed to proceed for $45 \mathrm{~min}$ and the cell solutions were then centrifuged at $150 \mathrm{~g}$ for $3 \mathrm{~min}$. The supernatants were harvested. $250 \mu \mathrm{l}$ of $25 \%$ trichloroacetic acid was added to each sample in order to precipitate protein and the supernatants were frozen. Histamine content of the samples was later determined by the automated fluorometric analysis method of Siraganian (26).

To determine the total histamine content within a sample, $0.5 \mathrm{ml}$ of whole blood was lysed with $0.5 \mathrm{ml}$ of $25 \%$ trichloroacetic acid and the solution was then centrifuged at $150 \mathrm{~g}$ for $3 \mathrm{~min}$. The supernatants were harvested and analyzed for histamine content as above.

Pharmacokinetic modeling. Measurements of serum CGP 51901 were fitted to a two compartment open model by means of PC-SAS version 6.11 The relationship between the half-life of the first phase of elimination of CGP 51901 and baseline free IgE was calculated using the Analytical Tools Regression option of Excel version 4.0.

\section{Results}

All the volunteers completed all visits up to 3 mo after dosing.

Baseline characteristics. There was no significant difference between the volunteers receiving placebo and those receiving CGP 51901 in terms of age or baseline serum IgE levels (Mann-Whitney U test) (Table I). 
Table I. Age of Volunteers and Baseline IgE for Placebo and Each Dosing Group

\begin{tabular}{lcc}
\hline Group & Mean age (range) & $\begin{array}{c}\text { Baseline IgE } \\
\text { IU/ml (range) }\end{array}$ \\
\hline Placebo & 22.2 & 295.1 \\
& $(18-30)$ & $(170-674)$ \\
$3 \mathrm{mg}$ & 34.5 & 290 \\
& $(18-48)$ & $(80 *-446)$ \\
$10 \mathrm{mg}$ & 31.5 & 359 \\
& $(20-49)$ & $\left(99 *-978^{*}\right)$ \\
$30 \mathrm{mg}$ & 19.8 & 239 \\
& $(18-22)$ & $(131-521)$ \\
$100 \mathrm{mg}$ & 34.2 & 395 \\
& $(19-52)$ & $(168-1079 *)$ \\
\end{tabular}

*IgE value was between $100-850 \mathrm{IU} / \mathrm{ml}$ at screening.

Intradermal skin testing to CGP 51901. There were no positive intradermal skin test reactions to CGP 51901.

Clinical effects. Throughout and after the infusion all volunteers remained hemodynamically stable with no signs or symptoms of anaphylaxis, serum sickness or allergic reactions. One patient receiving $100 \mathrm{mg}$ of CGP 51901 developed a mild increase in complement $\mathrm{C} 4$ levels to $0.6 \mathrm{~g} /$ liter (upper limit of normal $=0.35 \mathrm{~g} /$ liter $)$ at 6 and $8 \mathrm{~h}$ which returned to normal by $24 \mathrm{~h}$.

Free IgE. In volunteers receiving placebo levels of free IgE were monitored for up to $375 \mathrm{~d}$. Based on the mixed effect modelling of $\log (\mathrm{IgE})$, IgE levels in the volunteers receiving placebo fluctuated with a within subject variation of $28 \%$ and a between subject variation of $32 \%$.

After infusion of CGP 51901 there was an immediate fall in serum levels of free IgE. Fig. 1, $a$ and $b$ show the time-course of free $\mathrm{IgE}$ and total $\mathrm{IgE}$ levels in one volunteer receiving $3 \mathrm{mg}$ of CGP 51901 and one receiving $100 \mathrm{mg}$ of CGP 51901, respectively. The initial reduction in the level of free $\operatorname{IgE}$ in the volunteer receiving $3 \mathrm{mg}$ of CGP 51901 (Fig. $1 \mathrm{a}$ ) was from 335 $\mathrm{IU} / \mathrm{ml}$ (baseline) to $41 \mathrm{IU} / \mathrm{ml}$, and the reduction in the volunteer receiving $100 \mathrm{mg}$ of CGP 51901 (Fig. 1 b) was from 226 $\mathrm{IU} / \mathrm{ml}$ (baseline) to non-detectable levels within $0.5 \mathrm{~h}$ after in-

Table II. Mean Values of Maximum Total IgE (Mean C tot max $_{\text {) }}$ and Minimum Free IgE (Mean $C$ free $_{\text {min }}$ ) for Each Dosing Group and the Mean Time at Which Maximum Total (Mean T tot $_{\text {max }}$ ) and Minimum Free (Mean T free min $_{\text {m }}$ ) Were Reached for Each Group (only Including Actively Treated Volunteers)

\begin{tabular}{|c|c|c|c|c|}
\hline \multirow[b]{2}{*}{ CGP dose } & \multicolumn{2}{|c|}{ Total IgE } & \multicolumn{2}{|c|}{ Free IgE } \\
\hline & $\begin{array}{l}\text { Mean } \mathrm{T} \text { tot } \\
\text { (range) } \mathrm{h}\end{array}$ & $\begin{array}{l}\text { Mean } \mathrm{C} \text { tot } t_{\max } \\
\text { (range) } \mathrm{IU} / \mathrm{ml}\end{array}$ & $\begin{array}{l}\text { Mean } \mathrm{T} \text { free } \\
\quad \text { (range) } \mathrm{h}\end{array}$ & $\begin{array}{l}\text { Mean C free } \text { fin } \\
\text { (range) IU } / \mathrm{ml}\end{array}$ \\
\hline $3 \mathrm{mg}$ & $\begin{array}{c}53.9 \\
(6-96.17)\end{array}$ & $\begin{array}{c}495.8 \\
(289-671)\end{array}$ & $\begin{array}{c}5.7 \\
(0.5-23.67)\end{array}$ & $\begin{array}{c}53.8 \\
(25-70)\end{array}$ \\
\hline $10 \mathrm{mg}$ & $\begin{array}{c}136.3 \\
(20.8-334.6)\end{array}$ & $\begin{array}{c}700.8 \\
(332-1743)\end{array}$ & $\begin{array}{c}3.17 \\
(0.5-8)\end{array}$ & $\begin{array}{c}41.7 \\
(27-60)\end{array}$ \\
\hline $30 \mathrm{mg}$ & $\begin{array}{c}540.3 \\
(101.3-648.8)\end{array}$ & $\begin{array}{c}1147.3 \\
(443-2033)\end{array}$ & $\begin{array}{c}0.5 \\
(0.5-0.52)\end{array}$ & $\begin{array}{c}27 \\
(13-43)\end{array}$ \\
\hline $100 \mathrm{mg}$ & $\begin{array}{c}585.1 \\
(502.6-719.3)\end{array}$ & $\begin{array}{c}2317.0 \\
(1310-5497)\end{array}$ & $\begin{array}{c}2.3 \\
(0.48-7.98)\end{array}$ & $\begin{array}{c}7.3 \\
(0-10)\end{array}$ \\
\hline
\end{tabular}
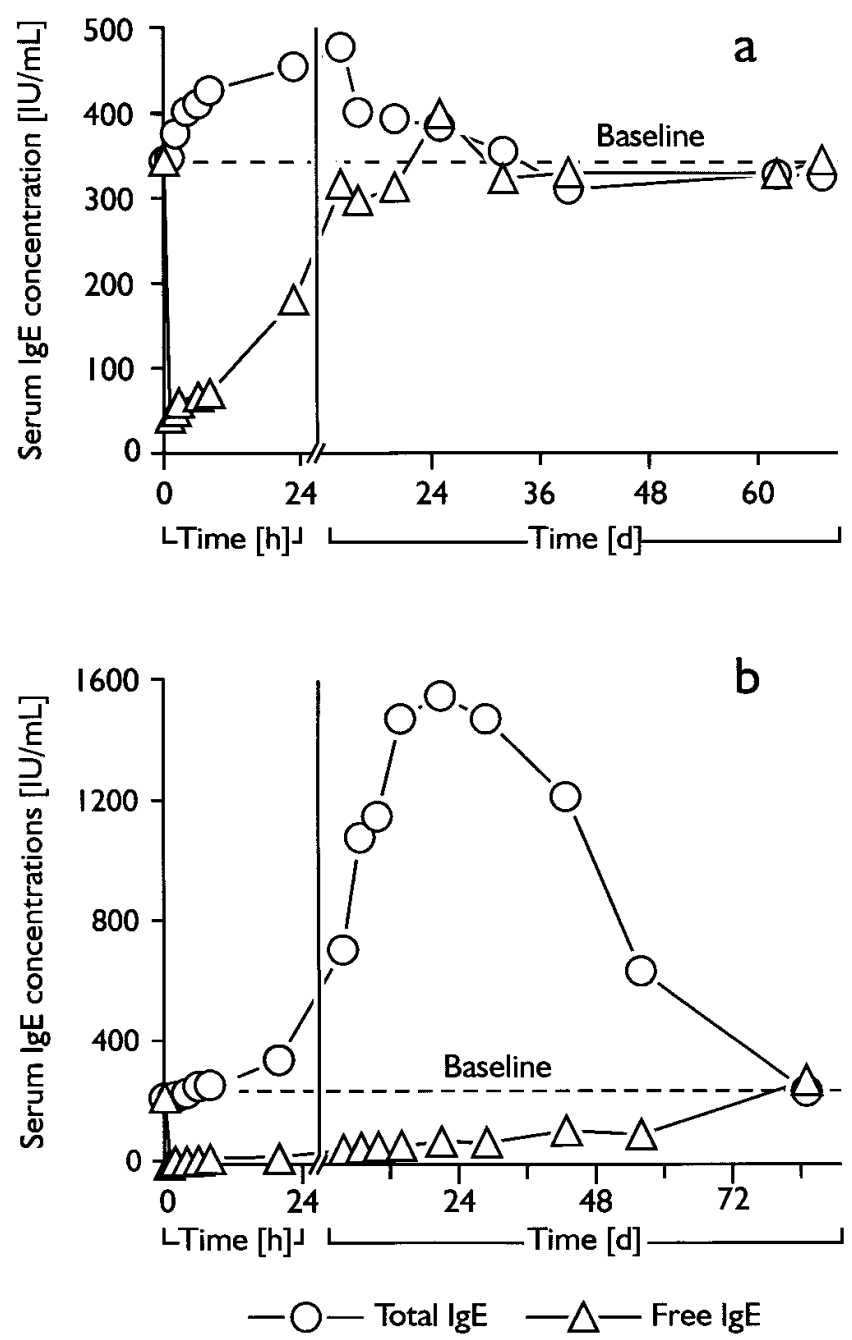

Figure 1. Serum concentrations of total $(\bigcirc)$ and free $(\triangle) \operatorname{IgE}$ measured in a volunteer before (time 0 ) and after receiving an infusion of (a) $3 \mathrm{mg}$ CGP 51901 and (b) $100 \mathrm{mg}$ CGP 51901. Baseline (---) represents concentration of serum $\operatorname{IgE}$ before the commencement of the infusion.

fusion. These results are representative of all volunteers receiving these doses. Minimum concentrations (6.1-31.3\% of baseline values) of free $\operatorname{IgE}$ were observed between 0.5 and $23 \mathrm{~h}$ in those receiving $3 \mathrm{mg}$ and $10 \mathrm{mg}$ of CGP $51901 \mathrm{respec}-$ tively. In those volunteers receiving $30 \mathrm{mg}$ of CGP 51901 the range of minimum free $\mathrm{IgE}$ was from $8 \%$ to $16.8 \%$ of baseline in the first $24 \mathrm{~h}$ and in the $100 \mathrm{mg}$ group minimum free $\mathrm{IgE}$ was $<1 \%$ to $6.7 \%$ of baseline. Table II shows the extent of free $\mathrm{IgE}$ reduction and the time points at which minimum free $\mathrm{IgE}$ levels were reached for each dosing group. The mean times required for restoring levels of free $\operatorname{IgE}$ to within $50 \%$ of baseline were 1.3, 5.3, 15.6, and $39 \mathrm{~d}$ for those receiving 3, 10, 30, and $100 \mathrm{mg}$ doses, respectively. Analysis of covariance (ANCOVA) demonstrated significant differences between minimum free IgE concentrations for all CGP 51901-treated volunteers compared with those receiving placebo $(P<0.0001$ for all doses).

Serum total IgE. Fig. 1, $a$ and $b$, shows the time-course of levels of total $\mathrm{IgE}$ (circulating free + circulating $\mathrm{IgE}$ complexed to CGP 51901) in two representative volunteers receiving 3 and $100 \mathrm{mg}$ of CGP 51901, respectively. After infusion of 

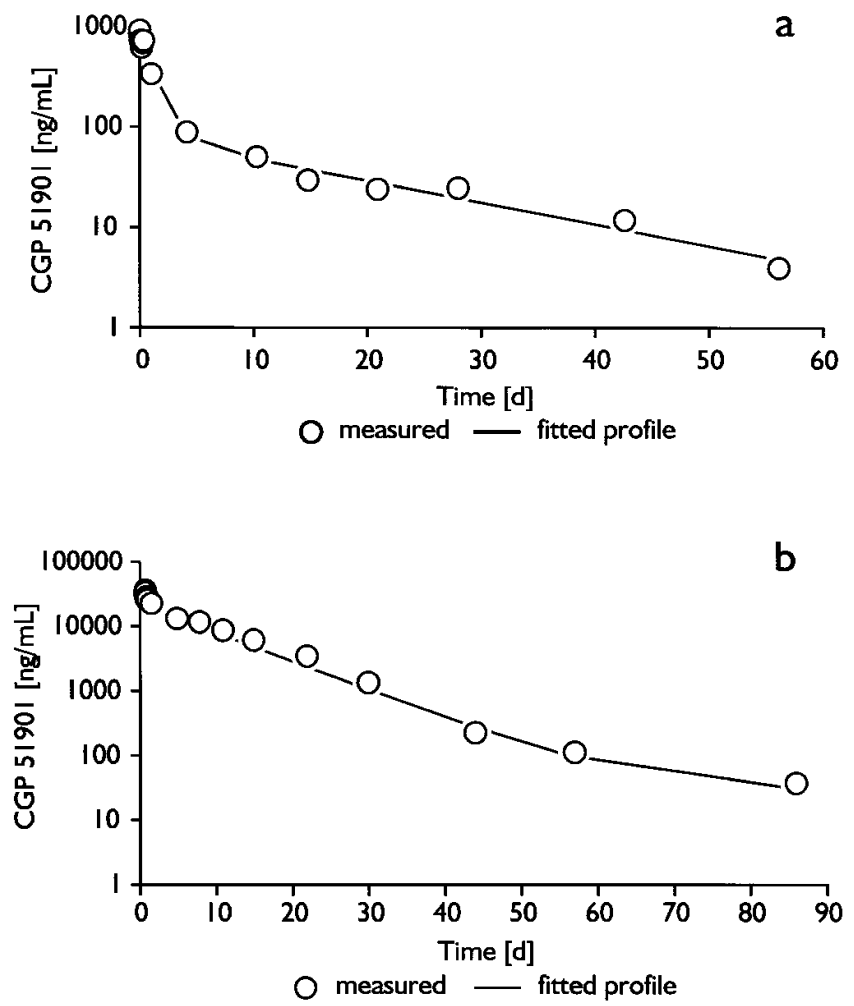

Figure 2. Serum concentrations of CGP 51901 in a volunteer after infusion of (a) $3 \mathrm{mg}$ and (b) $100 \mathrm{mg}$ of CGP 51901. (O) measured values; (-) fitted profile.

CGP 51901 the concentrations of total IgE increased in all treated volunteers. Maximum levels were up to 3.8-fold of baseline $\mathrm{IgE}$ in those receiving $3 \mathrm{mg}$ of CGP 51901, 4-fold in those receiving $10 \mathrm{mg}$, 6.1-fold in those receiving $30 \mathrm{mg}$ and 11.4-fold in the those receiving $100 \mathrm{mg}$ of CGP 51901. Levels reached the maximum between $6 \mathrm{~h}$ and $4 \mathrm{~d}$ for those receiving $3 \mathrm{mg}$ of CGP 51901, between 1 and $14 \mathrm{~d}$ for those receiving 10 $\mathrm{mg}$, between 4 and $21 \mathrm{~d}$ for those receiving $30 \mathrm{mg}$ and between 21 and $30 \mathrm{~d}$ for those receiving $100 \mathrm{mg}$. Maximum total $\mathrm{IgE}$ levels and the times at which these levels were observed are shown in Table II.

Serum CGP 51901. Fig. 2, $a$ and $b$, illustrates the timecourse of CGP 51901 levels in one volunteer receiving $3 \mathrm{mg}$ of CGP 51901 and one receiving $100 \mathrm{mg}$, respectively. They are representative of the CGP 51901 levels in all volunteers receiving these doses of CGP 51901. Elimination of CGP 51901 closely fitted the computer-generated curve for a 2-compartment open model (27). The initial phase of elimination ( $\alpha$ halflife) was negatively correlated with baseline $\mathrm{IgE}$ levels at all doses (Fig. 3) and positively correlated with the dose of CGP 51901. The second or terminal phase of elimination ( $\beta$ halflife) was similar for all doses ranging from 11-12 d, and was independent of both the baseline IgE and dose of CGP 51901. This phase was observed in all volunteers when CGP 51901 had reached a concentration approximately equivalent to $1 K_{\mathrm{d}}$ $(\sim 100 \mathrm{ng} / \mathrm{ml})$.

HPLC: analysis of serum IgE. The pharmacodynamic effects of CGP 51901 on serum IgE were further explored by HPLC analysis of serum samples at selected time-points. Fig. 4 shows the results from a volunteer treated with $30 \mathrm{mg}$ of CGP 51901. This shows that the increase in total IgE between 1 and
$10 \mathrm{~d}$ after infusion of CGP 51901 is associated with accumulation of complexes of IgE-CGP 51901. Between 1 and $4 \mathrm{~d}$ these are of heterogeneous sizes, presumably corresponding to bimolecular to tetramolecular complexes, whereas after $4 \mathrm{~d}$ tetramolecular complexes dominate. The serum half-life of IgECGP 51901 complexes has been estimated to be between 10 and $14 \mathrm{~d}$ based on numerous HPLC analyses and on the kinetics of serum total $\mathrm{IgE}$ decline after elimination of free CGP 51901 to or below its $K_{\mathrm{d}}$ concentration. Some complex dissociation occurs during dilution and separation during chromatography and this will cause trailing of originally complexed $\mathrm{IgE}$ into the peak area for free $\mathrm{IgE}$ thus leading to increased apparent levels of free IgE. Therefore, free $\operatorname{IgE}$ up to $10 \mathrm{~d}$ after treatment is less than is apparent in Fig. 4.

Anti-CGP. Only one volunteer, who received $10 \mathrm{mg}$ of CGP 51901, demonstrated measurable levels of anti-CGP 51901 antibodies of 143, 130 and $121 \mathrm{ng}$ equivalents/ml on days 13,28 , and 56, respectively. The elimination pharmacokinetics of CGP 51901 in this volunteer appeared similar to those of other individuals who received the $10 \mathrm{mg}$ dose.

Basophil histamine releasibility. Fig. 5 a shows the effect of infusion of CGP 51901 on basophil histamine release in response to ex vivo challenge with anti-IgE. Two volunteers (one receiving placebo and one receiving $10 \mathrm{mg}$ of CGP 51901) have been excluded from this analysis since their basophils released negligible $(<5 \%)$ histamine after challenge by all stimuli and so any change fell within the variability of background histamine release. There was no significant change in histamine release after treatment with either CGP 51901 or placebo in comparison with pretreatment levels and this was true for all doses of CGP 51901 administered. There were also no changes in spontaneous release of histamine from basophils (data not shown). In addition there were no changes observed in basophil histamine release in response to calcium ionophore A23187 or to the bacterial peptide fMLP at any of the time points for any of the doses tested (data not shown). Basal and anti-IgE induced histamine release was higher in the group receiving $100 \mathrm{mg}$ of CGP 51901. This was due to one individual who had exceptionally high levels of basal histamine release ( $>80 \%$ ). If this individual is removed form the analysis there is still no significant effect of administration of CGP 51901 on basophil histamine release.

Total histamine content within each blood sample was also calculated. Fig. $5 b$ illustrates the histamine concentration, which represents both stored and secreted histamine expressed per $\mathrm{ml}$ of blood. There were no changes observed in total histamine levels for placebo and 10 and $30 \mathrm{mg}$ of CGP 51901. Histamine levels were increased after administration of $100 \mathrm{mg}$ of CGP 51901 but this did not reach statistical significance and was due to increases in 2 out of the 5 volunteers receiving this dose. Follow-up studies on these volunteers indicated that histamine levels remained high at $57 \mathrm{~d}$ in one individual but returned to baseline in the other.

Skin prick tests. There was no significant difference in skin test reactivity to mixed grass pollen between those volunteers receiving CGP 51901 and those receiving placebo.

\section{Discussion}

In this first study of its kind we have shown that intravenous administration of an anti-human IgE antibody is safe and effective in reducing free $\mathrm{IgE}$ levels in atopic human volunteers. 

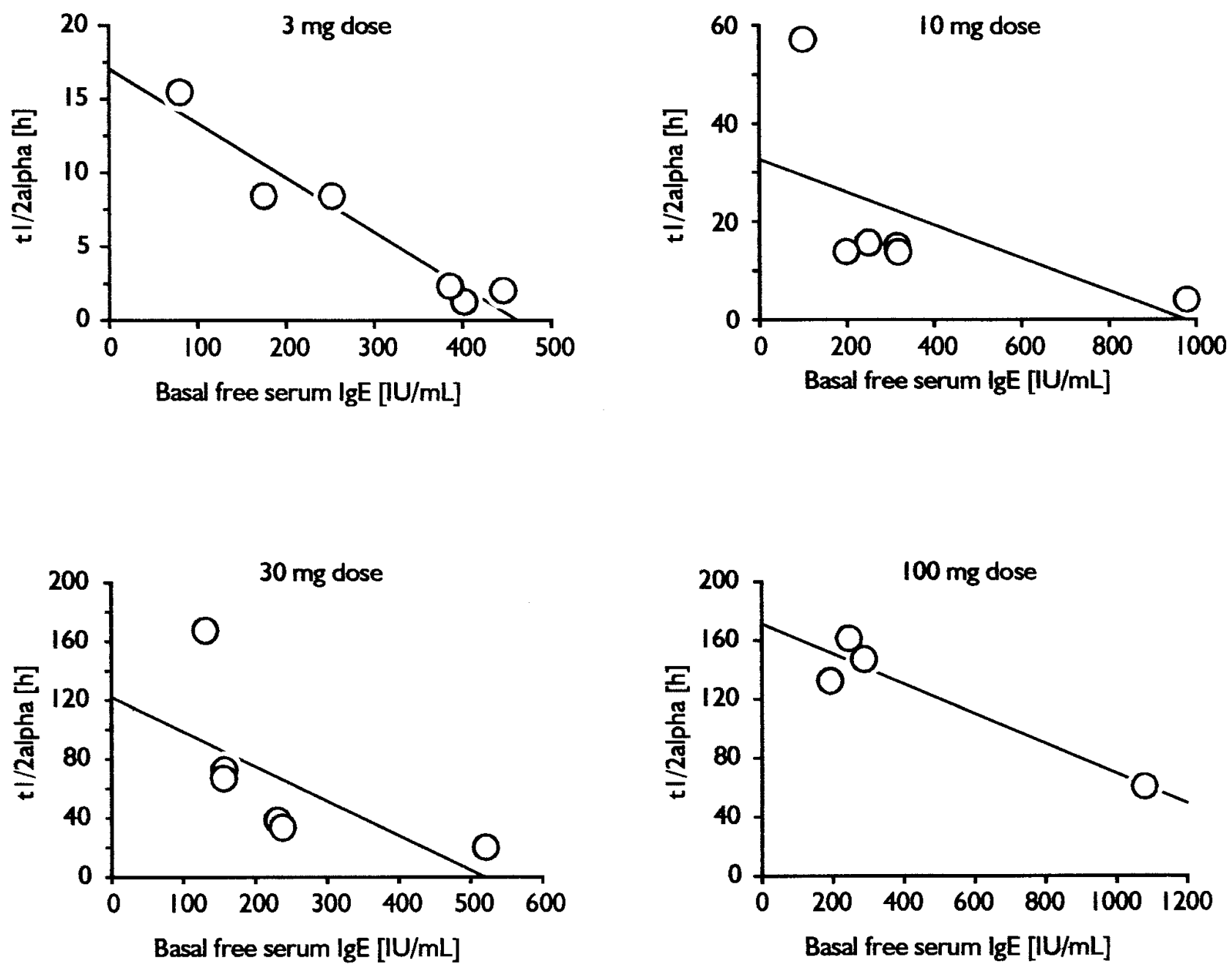

observed $\longrightarrow$ regr. line

Figure 3. Relationship between the half-life of first phase elimination $\left(t_{1 / 2}\right)$ of CGP 51901 and baseline free IgE for all doses of CGP 51901.

CGP 51901 was developed from an antibody selected from a panel of murine antibodies generated against human $\operatorname{IgE}$ (18). The parent antibody (TES-C21) was shown to bind with high affinity to free $\operatorname{IgE}$ and $\operatorname{IgE}$ expressed on the surface of B cells but not to induce histamine release from IgE-bearing basophils (18). Preincubation of IgE with the parent antibody prevented its binding to both high and low affinity IgE receptors and TES-C21 has been shown not to bind to cells bearing $\mathrm{IgE}$ already bound to high or low affinity receptors. This suggests that TES-C21 binds at or near the Fc receptor binding site of the $\operatorname{IgE}$ molecule located in its $\mathrm{C} \in 3$ domain (28), to an

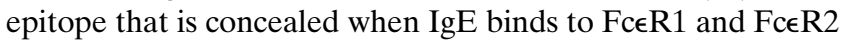
but is accessible on membrane anchored $\mathrm{IgE}$ of $\mathrm{IgE}$ expressing B cells. CGP 51901 is composed of the variable heavy $(\mathrm{H})$ and light (L) chain regions of TES-C21 linked to the human $\gamma 1$ and $\kappa$ constant regions. It has been shown to have the same binding properties as its parent murine antibody (18) and in vitro studies have demonstrated that it does not bind to other immunoglobulin isotypes nor to other circulating cells (18).

We have demonstrated that CGP 51901 is highly effective in reducing the levels of circulating free $\operatorname{IgE}$ by trapping $\operatorname{IgE}$ in the form of stable IgE-CGP 51901 complexes. The rapid reduction of free $\operatorname{IgE}$ after infusion of CGP 51901 is compatible with the fast association rate constants that are characteristic for high affinity antibodies. The time for free $\operatorname{IgE}$ to return to baseline was dependent on the dose of CGP 51901 and was negatively correlated with baseline IgE levels. At the highest dose $(100 \mathrm{mg})$ the amount of CGP51901 infused was between 15 to 100 times in excess of $\mathrm{IgE}$ in the total plasma volume at the time of infusion. At this dose total $\mathrm{IgE}$ levels (free and complexed) increased up to 11-fold of baseline levels within 21 to $30 \mathrm{~d}$. A pre-existing reservoir of $\mathrm{IgE}$, including Fc $\in \mathrm{R}$-bound $\mathrm{IgE}$ could contribute to some of the early rise in total $\mathrm{IgE}$ levels. However the prolonged and substantial rise of total $\mathrm{IgE}$, in the form of IgE-CGP 51901 complexes, appears to be mainly the result of continuous de novo synthesis of $\mathrm{IgE}$ at a rate compatible with the known kinetics of IgE turnover at which up to $80 \%$ of circulating IgE can be synthesized per day. While the short catabolic half-life of free $\operatorname{IgE}\left(t_{1 / 2} 1-2 \mathrm{~d}\right)(29)$ in equilibrium with de novo synthesis is responsible for maintaining $\operatorname{IgE}$ 


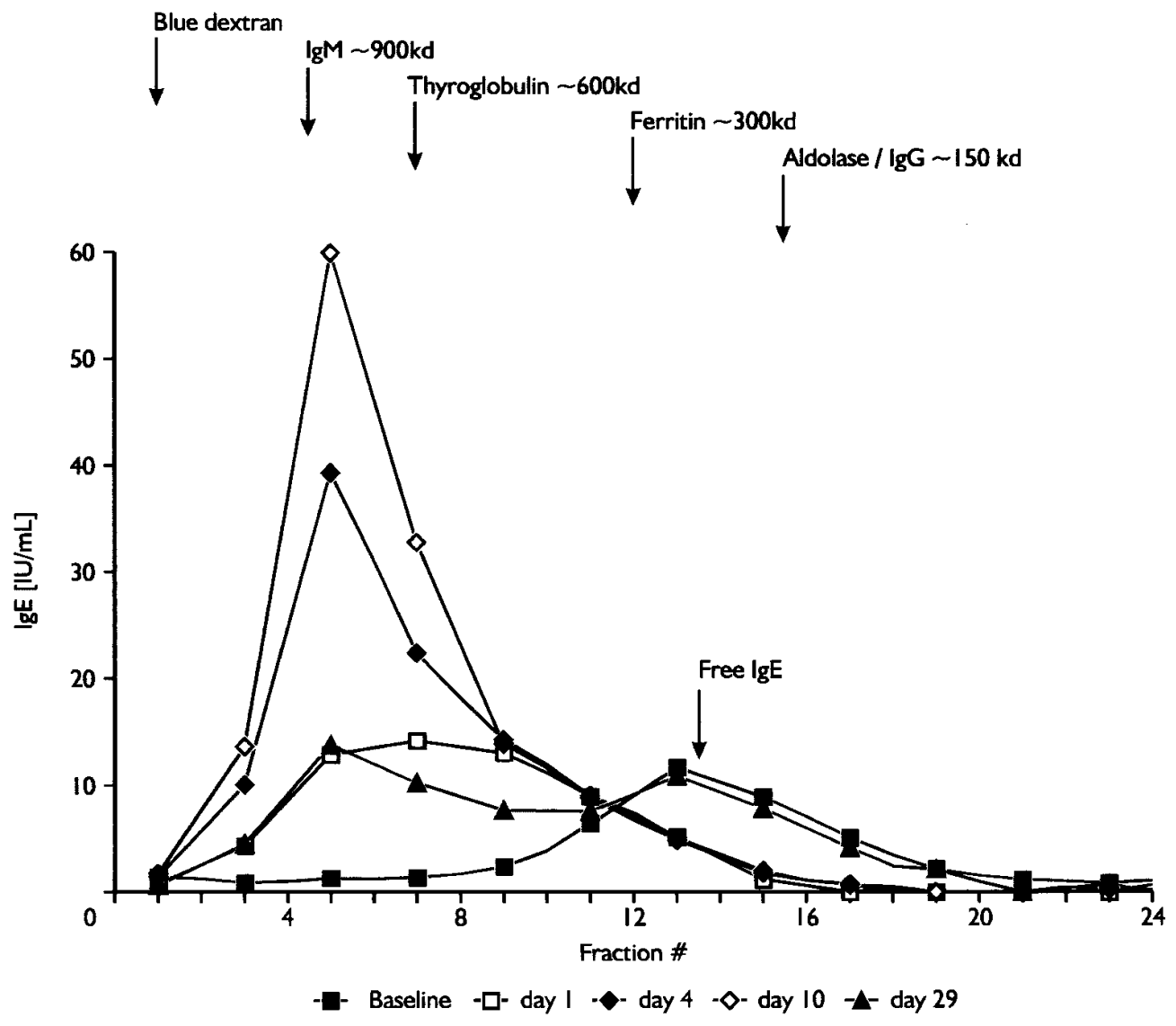

Figure 4. HPLC analyses of serum samples from a volunteer treated with $30 \mathrm{mg}$ of CGP 51901. Baseline $(\bullet)$ is serum obtained immediately before infusion of CGP 51901. The elution positions of reference proteins (with mol wt in $\mathrm{kD}$ ) and blue dextran (exclusion volume) used to calibrate the column are indicated by arrows. All column fractions were analysed for IgE concentration using the assay for total IgE. For clarity only the measurements of the uneven fractions were plotted. levels relatively constant in the physiological state we conclude that the much slower elimination rate of IgE-CGP 51901 complexes $\left(t_{1 / 2} 10-14 \mathrm{~d}\right)$ causes their accumulation in the circulation resulting in the observed rise of total $\mathrm{IgE}$ levels after CGP 51901 administration.

There was no clinical evidence that administration of CGP 51901 or the subsequent formation of CGP 51901-IgE complexes had an effect on mast cell or basophil histamine release which is in keeping with in vitro observations that CGP 51901 and IgE-CGP 51901 complexes do not bind to IgE on the surface of basophils and do not increase basophil histamine releasibility (18). This was confirmed by our ex vivo studies of histamine release from basophils isolated before and after infusion of CGP 51901. There was no increase in either spontaneous basophil histamine releasibility or that induced by anti-IgE or fMLP. An increase in total blood histamine levels was seen only after infusion of $100 \mathrm{mg}$ of CGP 51901 but did not reach statistical significance and was seen in two volunteers only. The basophils of these volunteers showed no increase in histamine releasibility in vitro and there was no detectable increase in absolute basophil numbers. Thus CGP 51901 does not bind to $\mathrm{IgE}$ on basophils to cause histamine release nor does it "prime" the cells for subsequent activation. It should be noted however that isolated basophils showed no decrease in histamine releasibility after administration of CGP 51901 suggesting that a single dose of up to $100 \mathrm{mg}$ had not depleted basophils of $\operatorname{IgE}$ within $8 \mathrm{~h}$ of the infusion.

Previously described chimeric antibodies have kinetics of elimination that fit a two-compartment model in agreement with the known kinetics of human $\operatorname{IgG}(30,31)$. The $\alpha$ phase elimination is due to antibody equilibration with the extravas- cular compartment and has a half-life of between 12 and $24 \mathrm{~h}$ and the $\beta$ phase is due to catabolism and has a half-life of about $10-14 \mathrm{~d}$ for chimeric $\mathrm{IgG} 1$. Although we have initially used two compartment kinetics to describe elimination of CGP 51901 it is clear from Fig. 2 that the division into $\alpha$ and $\beta$ half-life is not entirely applicable to CGP 51901 since an intermediate phase seems to exist between the initial and terminal phases of elimination. We propose that CGP 51901 is eliminated from the intravascular compartment by equilibration with the extravascular compartment (distribution), catabolism by the reticuloendothelial system, and also by complexing with newly formed IgE. The first phase of elimination is predominantly due to distribution, the intermediate phase predominantly due to complexing with $\operatorname{IgE}$ and the terminal phase, which begins when the concentration of CGP 51901 reaches that of its $K_{\mathrm{d}}$, due to catabolism. Thus the distribution phase occurs within the first 1-2 d whereas the half-life of the complexing phase is dependent on both the dose of CGP 51901 administered and levels of baseline IgE. The half-life of the catabolism phase appears to be independent of either levels of baseline free IgE or dose of CGP 51901 and was $11.8 \mathrm{~d}$, which is shorter than the reported half-life of IgG1 (32) but is consistent with previous observations with chimeric antibodies (31). This pattern of elimination should apply in general to monoclonal antibodies directed against continuously synthesized molecules such as IgE.

Despite the large fall in free $\operatorname{IgE}$ we have not demonstrated any change in skin prick test reactions to grass pollen although variability of the skin tests reduced the power of the study to detect any changes. The half-life of IgE on mast cells has been estimated at $13 \mathrm{~d}$ (33) and so it is probable that, unless CGP 

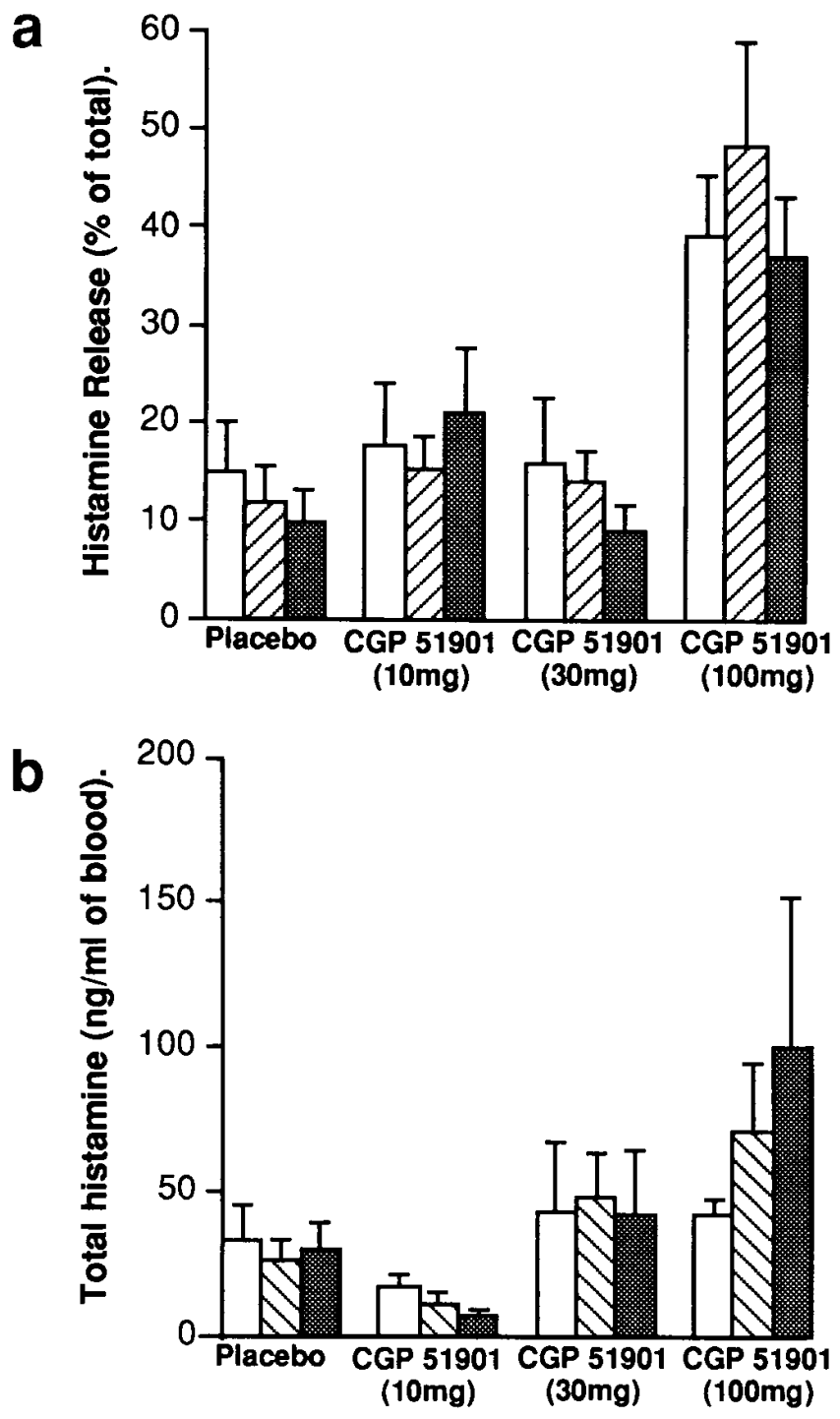

Figure 5. (a) The effect of administration of placebo and CGP 51901 on anti-IgE induced histamine release from circulating basophils. Blood samples were obtained before administration of CGP 51901 or placebo (open bars), and $6 \mathrm{~h}$ (hatched bars), and $8 \mathrm{~h}$ (shaded bars) after treatment. Basophils were challenged with anti-IgE $(1 \mu \mathrm{g} / \mathrm{ml})$ and incubated at $37^{\circ} \mathrm{C}$ for $45 \mathrm{~min}$ and histamine release was then determined. Results are expressed as mean \pm standard error of the mean. (b) The effect of placebo and CGP 51901 on total blood histamine content. Blood samples were obtained before infusion of CGP 51901 or placebo (open bars), and $6 \mathrm{~h}$ (hatched bars) and $8 \mathrm{~h}$ (shaded bars) after treatment. Aliquots of whole blood were lysed with $25 \%$ trichloroacetic acid and histamine content with the supernatants determined. Results are expressed as mean \pm standard error of the mean.

51901 is able to strip IgE off Fc $\in \mathrm{R} 1$ receptors, which our data on basophil histamine releasibility suggests is unlikely, multiple dosing, resulting in depletion of free $\mathrm{IgE}$ for more than 2 weeks, will be required to produce an effect on IgE-mediated mast cell function in the skin or elsewhere.

Infusion of CGP 51901 was well tolerated by all subjects. Only one volunteer developed significant although low levels of anti-CGP 51901 antibodies and there were no clinically significant consequences of antibody development. None of the volunteers experienced a cutaneous reaction to intradermal in- jection of CGP 51901 nor symptoms or signs of anaphylaxis after its administration. These findings support the view obtained from previous in vitro studies that CGP 51901 does not cross-link receptor bound IgE. The low immunogenicity of this chimeric antibody is in keeping with the fusion of a mouse variable region to a human constant region since $90 \%$ of the antibody response after repeated administration of a xenogeneic monoclonal antibody is directed against the constant region (20). However, some antibody response is to be expected in view of previous reports of immune responses to mouse/human chimeric antibodies which may adversely effect the pharmacokinetics of repeat infusions (34). In this single dose study the level of anti-CGP antibody detected, in one volunteer receiving $10 \mathrm{mg}$ of CGP 51901, would not have been enough to adversely effect the pharmacokinetics of even a $3 \mathrm{mg}$ dose of CGP 51901. Nevertheless, further studies will be needed to determine whether repeated administration of CGP 51901 might induce higher immune responses that would significantly reduce the efficacy of long-term treatment.

By its nature CGP 51901 forms complexes with $\mathrm{IgE}$ and therefore offers a potential for the development of circulating immune complexes with possible adverse effects. This, however, is unlikely due to the small size of the tetrameric CGP 51901-IgE complexes formed and the relatively low concentration of complexes accumulating even in individuals with very high IgE levels. The greatest increase in total serum IgE level was from $1000 \mathrm{IU} / \mathrm{ml}$ to $5500 \mathrm{IU} / \mathrm{ml}$ and was observed in a volunteer who was treated with $100 \mathrm{mg}$ CGP 91501. This corresponds to about $24 \mu \mathrm{g} / \mathrm{ml}$ of IgE/CGP 51901 complexes, which falls within the lower range of natural immune complexes in healthy individuals (35). Because the amount of total serum IgE and IgE-CGP 51901 complexes that accumulate are dependent on de novo synthesis of $\mathrm{IgE}$ the maximum accumulation of IgE-CGP 51901 immune complexes is not expected to increase beyond that observed for the $100 \mathrm{mg}$ single dose of CGP 51901. It should also be noted that only one subject in this study developed any changes in complement levels which was a small rise that resolved by $24 \mathrm{~h}$.

Finally, the long-term safety implications of administration of CGP 51901 are important if this form of treatment is to enter clinical practice. One putative role of $\mathrm{IgE}$ is protection against parasitic disease (36). However, protection against parasites is not solely an IgE-dependent response but also involves cellular and other humoral components (37). IgE-deficient mice infected with helminths show no difference in worm burden after primary infection or resistance to secondary infection when compared to IgE-producing control mice (38). Other studies have shown that when infected with Leishmania high $\operatorname{IgE}$ responding $\mathrm{BALB} / \mathrm{c}$ mice have a higher mortality than low $\mathrm{IgE}$ responding BALB/c mice. Furthermore, administration of an anti-IL4 antibody to the high-IgE responders, which knocks out their $\mathrm{IgE}$ response, reduces their mortality to that of the low responding group (39). Similarly another study demonstrated that anti-IgE treatment was beneficial in Schistosoma infected mice (40). Some authors have suggested that atopy may protect against the development of neoplasia $(41,42)$ but others have failed to corroborate these findings $(43,44)$ and they relate the diminished risk of cancer to atopy and not specifically to IgE levels. It must also be remembered that CGP 51901 reduces circulating levels of IgE in atopic individuals to low levels commonly seen in non-atopic individuals.

In conclusion the chimeric antibody, CGP 51901, was effec- 
tive in reducing levels of circulating free $\operatorname{IgE}$ for a prolonged period after a single intravenous administration. It was well tolerated and did not cause serum sickness or immune complex disease. Therefore CGP 51901 warrants further evaluation in phase II studies for asthma and allergic rhinitis where $\mathrm{IgE}$ is considered to play a key triggering role.

\section{Acknowledgments}

We would like to acknowledge Kirstin Goldring and Sandra Lavens for their help with the basophil assays; Peter Spies, Adelaida Weber, and Mattias Frommherz for technical assistance; and Karen Sampson, Anne-Marie Archer, and Pam Hurst for nursing assistance.

This study was funded by Ciba-Geigy Ltd. J. Corne, R. Djukanovic, and S. Holgate are funded by the Medical Research Council (UK).

\section{References}

1. Gergen, P., and K. Weiss. 1994. Epidemiology of asthma. In Asthma and Rhinitis. S.T. Holgate and W.W. Busse, editors. Blackwell Scientific, Cambridge, MA. 15-31.

2. Weis, K.B., P.J. Gergen, and T.A. Hodgson. 1992. An economic evaluation of asthma in the United States. N. Engl. J. Med. 326:862-866.

3. Burrows, B., F.D. Martinez, M. Holonen, R.A. Barbee, and M.G. Cline. 1989. Association of asthma with serum IgE levels and skin test reactivity to allergens. N. Engl. J. Med. 320:271-277.

4. Sears, M.R., B. Burrows, E.M. Flannery, G.P. Herbison, C.J. Hewitt, and M.D. Holdaway. 1991. Relation between airway responsiveness and serum IgE in children with asthma and in apparently normal children. N. Engl. J. Med. 325: 1067-1071.

5. Sunyer, J., A. Munoz, and Spanish Group of the European Asthma Study. 1996. Concentration of Methacholine for bronchial responsiveness according to symptoms, smoking, and Immunoglobulin E in a population based study in Spain. Am. J. Respir. Crit. Care Med. 153:1273-1279.

6. Pollart, S., M. Chapman, G. Fiocco, G. Rose, and A. Platts-Mills. 1989. Epidemiology of acute asthma: IgE antibodies to common inhalant allergens as a risk factor for emergency room visits. J. Allergy Clin. Immunol. 83:875-882.

7. Lichtenstein, L., K. Ishizaka, P. Norman, A. Sobotka, and B. Hill. 1973. IgE antibody measurements in ragweed hay fever. J. Clin. Invest. 52:472-482.

8. Naclerio, R., N. Adkinson, Jr, P. Creticos, F. Baroody, R. Hamilton, and P. Norman. 1993. Intranasal steroids inhibit seasonal increases in ragweed-specific immunoglobulin E antibodies. J. Allergy Clin. Immunol. 92:717-721.

9. Bradding, P., J. Roberts, K. Britten, S. Montefort, R. Djukanovic, R. Mueller, C. Heusser, P. Howarth, and S. Holgate. 1994. IL-4,-5,-6 and TNF $\alpha$ in normal and asthmatic airways: evidence of the human mast cell as a source of these cytokines. Am. J. Respir. Cell Mol. Biol. 10:471-480.

10. Bradding, P. Feather, P. Howarth, R. Mueller, J. Roberts, K. Britten, J. Bews, T. Hunt, Y. Okayama, C. Heusser, G. Bullock, M. Church, and S. Holgate. 1992. Interleukin 4 is localized to and released by human mast cells. $J$. Exp. Med. 176:1381-1386.

11. Bradding, P., R. Mediwake, I. Feather, J. Madden, M. Church, S. Holgate, and P. Howarth. 1995. TNF $\alpha$ is localized to nasal mucosal mast cells and is released in acute rhinitis. Clin. Exp. Allergy. 25:406-415.

12. Okayama, Y., C. Petit-Frere, O. Kassel, A. Semper, D. Quint, M.J. Tunon-de-Lara, P. Bradding, S.T. Holgate, and M.K. Church. 1995. IgE-dependent expression of mRNA for IL-4 and IL-5 in human lung mast cells. J. Immunol. 155:1796-1808.

13. Maurer, D., C. Ebner, B. Reininger, E. Fiebiger, D. Kraft, J. Kinet, and G. Stingl. 1995. The high affinity IgE receptor (FceR1) mediates IgE-dependent allergen presentation. J. Immunol. 154:6285-6290.

14. Reischl, I., N. Corvaia, F. Effenberger, B. Wolff-Winiski, E. Kromer, and G. Mudde. 1996. Function and regulation of FceR1 expression on monocytes from non-atopic donors. Clin. Exp. Allergy. 26:630-641.

15. Pirron, U., T. Schlunk, J. Prinz, and E. Rieber. 1990. IgE dependent antigen focusing by human $\mathrm{B}$ lymphocytes is mediated by the low affinity receptor for IgE. Eur. J. Immunol. 20:1547-1551.

16. Coyle, A., K. Wagner, C. Bertrand, S. Tsuyuki, J. Bews, and C. Heusser. 1996. Central role of Immunoglobulin (Ig) $\mathrm{E}$ in the induction of lung eosinophil infiltration and $\mathrm{T}$ helper 2 cell cytokine production: Inhibition by a non-anaphylactogenic anti-IgE antibody. J. Exp. Med. 183:1303-1310.

17. Brusselle, G., J. Kips, J. Tavernier, J. Van der Heyden, C. Cuvelier, R. Pauwels, and H. Bluethmann. 1994. Attenuation of allergic airway inflammation in IL-4 deficient mice. Clin. Exp. Allergy. 24:73-80.

18. Davis, F., L. Gossett, K. Pinkston, R. Liou, L. Sun, Y. Kim, N. Chang, K. Wagner, J. Bews, V. Brinkman, H. Towbin, N. Subramanian, and C. Heusser.
1993. Can anti-IgE be used to treat allergy. Springer Semin. Immunopathol. 15: $51-73$.

19. Khazaeli, M., M. Saleh, T. Liu, R. Meredith, R. Wheeler, T. Baker, D. King, D. Seeher, L. Allen, K. Rogers, D. Colcher, J. Schlom, D. Shochat, and A. LoBuglio. 1991. Pharmakokinetics and immune response of 131 I-chimaeric mouse/human B72-3 (human gamma 4) monoclonal antibody in humans. Cancer Res. 51:5461-5466.

20. Bruggemann, M., G. Winter, H. Waldmann, and M. Neuberger. 1989. The immunogenicity of chimeric antibodies. J. Exp Med.170:2153-2157.

21. Roberts, S., J. Cheetham, and A. Rees. 1987. Generation of an antibody with enhanced affinity and specificity for its antigen by protein engineering. $\mathrm{Na}$ ture (Lond.). 328:731-734.

22. Malling, H.-J. Methods of skin testing. Eur. J. Allergy Clin. Immunol. 48s:55-56.

23. D'Ambrosio, S., R. Gibson-D'Ambrosio, and R. Trewyn. 1991. An enzyme-linked immunosorbent assay (ELISA) for the detection and quantitation of the tumor marker 1-methylinosine in human urine. Clin. Chim. Acta. 199: 119-128.

24. Bodmer, D., L. Tiefenauer, and R. Andres. 1989. Antigen-versus antibody-immobolized ELISA procedures based on a biotinyl-estradiol conjugate. J. Steroid Biochem. Mol. Biol. 33:1161-1166.

25. Warner, J., A. Reshef, and D.J. MacGlashan. 1987. A rapid technique for the purification of human basophils. J. Immunol. Methods. 105:107-110.

26. Siraganian, R. 1974. An automated continuous flow system for the extraction and fluorometric determination of histamine. Annal. Biochem. 57:283287.

27. Gibaldi, M., and D. Perrier. 1982. Pharmacokinetics. 2nd ed. Marcel Dekker Inc., New York. 352 pp.

28. Helm, B., P. Marsh, D. Vercelli, E. Padlan, H. Gould, and R. Geha. 1988. The mast cell binding site on human immunoglobulin E. Nature (Lond.). 331:180-183.

29 Klein, J. 1982. Immunology. The Science of Self Non-Self Discrimination. John Wiley and Sons, New York. 1284 pp.

30. Solomen, A., T. Waldmann, and J. Fahey. 1963. Metabolism of normal $6.6 \gamma$ globulin in normal subjects and in patients with macroglobulinemia and multiple myeloma. J. Lab. Clin. Med. 62:1-17.

31. LoBuglio, A., R. Wheeler, J. Trang, A. Haynes, K. Rogers, E. Harvey, L. Sun, J. Ghrayeb, and M. Khazaeli. 1989. Mouse/human chimeric monoclonal antibody in man: Kinetics and immune response. Proc. Natl. Acad. Sci. USA. $86: 4220-4224$

32. Morell, A., W. Terry, and T. Waldmann. 1970. Metabolic properties of IgG subclasses in man. J Clin. Invest. 49:673-680.

33. Siraganian, R. 1988. Mast cells and basophils. In Inflammation: Basic Principles and Clinical Correlates. J. Gallin, I. Goldstein, and R. Snyderman, editors. Raven Press, New York. 513-542.

34. Khazaeli, M., M. Saleh, T. Liu, R. Meredith, R. Wheeler, T. Baker, D. King, D. Secher, L. Allen, K. Rogers, D. Colcher, J. Schlom, D. Schochat, and A. LoBuglio. 1991. Pharmacokinetics and immune response of 131I-chimeric mouse/human B72.3 (human $\gamma 4$ ) monoclonal antibody in humans. Cancer Res. $51: 5461-5466$.

35. Contreras, C., A. Orozco, P. Sanchez, G. Ortega, and N. Bianco. 1982. Physiological aspects of circulating immune complexes in the normal population. Clin. Exp. Immunol. 48:693-699.

36. Rihet, P., C. Demeure, A. Bourgois, A. Prata, and A. Dessein. 1991. Evidence for an association between human resistance to Schistosoma mansoni and high anti-larval IgE levels. Eur. J. Immunol. 21:2679-2686.

37. Velge-Roussel, F., C. Auriault, M. Damonneville, and A. Capron. 1991. Functional analysis of a $\mathrm{T}$ cell line specific for antiidiotypic antibodies to a Schistosoma mansoni protective epitope. II. Induction of protective immunity in experimental rat schistosomiasis. J. Immunol. 147:3967-3972.

38. Watanabe, N., K. Katakura, A. Kobayashi, K. Okumura, and Z. Ovary. 1989. Protective immunity and eosinophilia in IgE-deficient SJA/9 mice infected with Nippostrongylus brasiliensis and Trichinella spiralis. Proc. Natl. Acad. Sci. USA. 85:4460-4462.

39. Sadick, M., F. Heinzel, B. Holaday, R. Pu, R. Dawkins, and R. Locksley. 1990. Cure of murine Leishmaniasis with an anti-IL-4 monoclonal antibody. $J$. Exp Med.171:115-123.

40. Amiri, P., M. Haak-Frendscho, K. Robbins, J. McKerrow, T. Stewart, and P. Jardieu. 1994. Anti-immunoglobulin E treatment decreases worm burden and egg production in Schistisoma mansoni infected normal and IFN-g knockout mice. J. Exp Med. 180:43-51.

41. Fisherman, E. 1960. Does the allergic diathesis influence malignancy Allergy. 31:74-78.

42. Allegra, J., A. Lipton, H. Harvey, J. Luderer, D. Brenner, R. Mortel, L. Semers, M. Gillin, D. White, and J. Trautlein. 1976. Decreased prevalence of immediate hypersensitivity (atopy) in a cancer population. Cancer Res. 36: 3225-3226.

43. McKee, W., C.A. Arnold, and M. Perlman. 1967. A double blind study of the comparative incidence of malignancy and allergy. J. Allergy Clin. Immunol. 39:294-301.

44. Shapiro, S., O. Heinonen, and V. Siskind. 1971. Cancer and allergy. Cancer. 28:396. 